\title{
HUBUNGAN JUMLAH KONSUMSI BISKUIT PMT-P DENGAN KENAIKAN BERAT BADAN PADA BALITA GIZI KURANG USIA 12-24 BULAN
}

\author{
Besti Verawati $^{1}$, Nopri Yanto $^{2}$, Cira Octa Weydia Nova ${ }^{3}$ \\ S1 Gizi Universitas Pahlawan Tuanku Tambusai ${ }^{1,3}$ \\ S1Keperawatan Universitas Pahlawan Tuanku Tambusai ${ }^{2}$ \\ bestiverawati167@gmail.com ${ }^{1}$,nopri.ipb@gmail.com ${ }^{2}$
}

\begin{abstract}
Toddlers are children under five years of age characterized by a very rapid growth and development process. At this time, toddlers need nutrients that are more in number and of good quality, but toddlers are prone to nutritional disorders and are prone to disease due to lack of the food they need. The purpose of this study was to analyze the relationship between the amount of PMT-P biscuit consumption and weight gain in undernourished children aged 12-24 months. This type of quantitative research with cross sectional method. The study was conducted at the Muara Fajar inpatient health center in May-August 2020 with a sample of 52 toddlers. The technique of collecting data was an interview with the mother using a questionnaire. The analysis used univariate and bivariate analysis with Chi Square test. The results of the univariate analysis showed that as many as 29 toddlers (55.8\%) gained weight and 29 toddlers (55.8\%) according to the amount in consuming PMT-P biscuits. Bivariate analysis showed a significant relationship between the number of PMT-P biscuits and the weight gain of undernourished children under five with $P$-value $<0.05$. The appropriate amount of PMT-P can increase body weight in undernourished toddlers.
\end{abstract}

Keywords $\quad$ : PMT-P Biscuits, Undernourished Children Under Five, Weight Gain Of Toddlers.

\begin{abstract}
ABSTRAK
Balita adalah anak usia dibawah lima tahun yang ditandai dengan proses pertumbuhan dan perkembangan yang terjadi sangat pesat. Pada masa ini, balita memerlukan zat-zat gizi yang jumlahnya lebih banyak dan berkualitas namun balita mudah menderita kelainan gizi dan rawan penyakit karena kekurangan makanan yang dibutuhkan. Tujuan penelitian ini adalah menganalisis hubungan jumlah konsumsi biskuit pemberian makanan tambahan pemulihan (PMT-P) dengan kenaikan berat badan pada balita gizi kurang usia 12-24 bulan. Jenis penelitian kuantitatif dengan metode cross sectional. Penelitian dilakukan di puskesmas rawat inap muara fajar pada Bulan MeiAgustus 2020 dengan jumalah sampel 52 balita. Teknik pengumpulan data wawancara dengan ibu menggunakan kuesioner. Analisis yang digunakan yaitu analisis univariat dan bivariate dengan uji Chi Square. Hasil analisa univariat menunjukkan sebanyak 29 balita $(55,8 \%)$ naik berat badan dan 29 balita $(55,8 \%)$ sesuai jumlah dalam mengkonsumsi biskuit PMT-P. Analisis bivariat menunjukkan terdapat hubungan yang signifikan antara jumlah pemberian biskuit PMT-P dengan kenaikan berat badan balita gizi kurang dengan $\mathrm{P}$ value $<0.05$. jumlah pemberian PMT-P yang sesuai dapat menaikkan berat badan pada balita gizi kurang.
\end{abstract}

Kata Kunci : Balita Gizi Kurang, Jumlah Pemberian Biskuit, Kenaikan Berat Badan Balita

\section{PENDAHULUAN}

Masa balita merupakan periode penting dalam proses tumbuh kembang manusia. Perkembangan dan pertumbuhan di masa itu menjadi penentuk keberhasilan pertumbuhan dan perkembangan anak di periode selanjutnya. Masa tumbuh kembang di usia ini merupakan masa yang berlangsung cepat dan tidak akan pernah terulang, karena itu sering disebut golden age atau masa keemasan (Uripi, 2014). 
Orang tua memiliki peran penting untuk memberikan yang terbaik bagi anaknya utamanya sampai berumur 5 tahun. Usia balita adalah periode yang sangat rentan. Jika balita tidak mendapat perhatian maka sudah dipastikan balita akan mengalami perkembangan yang tidak sempurna, penurunan kemampuan fisik, rendahnya tingkat kecerdasan, penurunan daya tahan tubuh sehingga rentan terhadap penyakit infeksi. Balita yang menderita penyakit infeksi akan mengalami gangguan nafsu makan dan penyerapan zat-zat gizi sehingga menyebabkan gizi kurang (Adrini M, 2014).

Gizi kurang merupakan suatu kondisi Berat Badan menurut Umur $(\mathrm{BB} / \mathrm{U})$ tidak sesuai dengan usia seharusnya. Menurut Profil Kesehatan RI, 2017 "Gizi kurang dan buruk merupakan status gizi yang didasarkan pada indeks BB/U. Persentase Kurus dan sangat kurus pada balita 0-59 bulan di Indonesia $2,80 \%$ dan 6,70\%. Untuk di Provinsi Riau mencapai 4,0\% dan 8,6\% (Kesehatan RI, 2018). Sementara itu untuk wilayah kota Pekanbaru Balita Garis Merah (BGM) dengan status gizi kurang pada tahun 2017 mengalami penurunan yang pada awalnya di tahun 2016 balita dengan status gizi kurang berjumlah 0,6\% tetapi di tahun 2017 menjadi 0,5\%. Menurut profil Puskesmas Muara Fajar tahun 2017 dan 2018 balita gizi kurang mencapai $3.31 \%$ sedangkan pada tahun 2019 meningkat menjadi $3.35 \%$.

Faktor yang mempengaruhi status gizi meliputi 2 hal, faktor langsung dan tidak langsung. Faktor langsung antara lain asupan makan dan penyakit infeksi sedangkan faktor tidak langsung yaitu pola asuh, ketersediaan pangan dan sanitasi (Hardinsyah 2019). Asupan zat gizi merupakan salah satu penyebab langsung yang dapat mempengaruhi status gizi balita. Asupan gizi dapat diperoleh dari beberapa zat gizi, diantaranya yaitu zat gizi makro seperti energi, karbohidrat, protein dan lemak (Verawati B 2018). Faktor yang lainnya yaitu penyakit infeksi yang kemudian akan menyebabkan gangguan nafsu makan dan penyerapan zat-zat gizi sehingga menyebabkan kurangnya gizi. Sedangkan penyebab tidak langsung salah satunya adalah pola asuh. Badan Kesehatan Dunia Word Health Organisasion (WHO) dan United Nations International Children's Emergency Fund (UNICEF) telah merekomendasikan pola asuh makanan yang sesuai untuk balita yaitu pemberian ASI Ekslusif selama 6 bulan dan dilanjutkan dengan pemberian Makanan Pendamping ASI (MP-ASI) yang sesuai dengan usia balita.

Asupan makanan atau pemberian makanan pada balita tidak hanya terkait dengan ketersediaan tetapi juga harus memperhatikan 6 syarat. Adapun 6 syarat pemberian makanan balita adalah frekuensi, jumlah, tekstur, jenis, aktif dan kebersihan. Jika dalam pemberian makanan mengacu kepada 6 syarat tersebut maka dapat membantu dalam kenaikan berat badan balita (Heronimus T S, et al, 2017).

Frekuensi pemberian makanan pada balita dilakukan 2-3 kali untuk makanan pokok dan 1-2 kali untuk selingan. Sedangkan jumlah pemberian makanan tergantung kepada daya terima balita. Upaya yang dapat dilakukan pemerintah dalam rangka mencukupi kekurangan kebutuhan gizi dan konsumsi makan harian yang berakibat pada timbulnya masalah kesehatan dan gizi pada kelompok rawan gizi yaitu dengan suplementasi makanan berupa Pemberian Makanan Tambahan Balita Pemulihan (PMT-P) dalam bentuk Biskuit Balita. Untuk usia 12-59 bulan biskuit diberikan 3 bungkus (12 keping) per hari atau setara dengan 480 kalori. Apabila PMT-P diberikan dengan frekuensi dan jumlah yang tepat maka ini dapat meningkatkan berat badan balita hingga 1 $\mathrm{kg}$ setiap bulannya. Penelitian Fitriyanti Farida, et al, 2012 menjelaskan bahwa PMT-P memberikan pengaruh signifikan terhadap perubahan status gizi berdasarkan Berat Badan Menurut Tinggi Badan (BB/TB) dan Berat Badan Menurut Umur (BB/U) demikian pula dengan penelitian yang dilakukan Maisarah et al, (2018) yang 
menunjukkan adanya perbedaan yang bermakna perubahan status gizi balita sebelum dan sesudah PMT-P pada balita gizi buruk.

Kekurangan gizi pada usia balita memiliki dampak adanya penurunan sistem kekebalan tubuh sehingga mudah terserang penyakit infeksi. Penyakit infeksi seperti diare, pneumonia, malaria, campak atau measless dan AIDS diketahui paling banyak menyebabkan kematian pada anak balita dengan gizi buruk (Maisarah, 2018). Peneilitian ini bertujuan untuk melihat hubungan jumlah konsumsi biskuit PMTPemulihan dengan kenaikan berat badan pada balita gizi kurang usia 12-24 bulan.

\section{METODE}

Penelitian ini merupakan penelitian kuantitatif dengan desain cross sectional. Penelitian dilakukan di Puskesmas Rawat Inap Muara Fajar pada bulan Mei-Agustus 2020. Sampel penelitian ini berjumlah 52 orang yang diperoleh secara total sampling, dengan Kriteria sampel Kriteria Inklusi Balita yang berusia 12-24 bulan dengan status gizi kurang, Mendapat Makanan Tambahan Pemulihan (MT-P) 2 bulan sebelum pengambilan data dilakukan, Ibu balita yang bersedia menjadi responden/diwawancarai, kriteria ekslusi merupakan balita gizi kurang dengan penyakit penyerta Ibu Balita yang tidak bersedia menjadi responden

Variable pada penelitian ini terdiri dari variable Independent yaitu jumlah pemberian PMT-P dan Variabel Depenedent yaitu kenaikan berat badan. Jumlah pemberian PMT-P diperoleh dengan wawancara kepada ibu balita menggunakan kuesioner dan kenikkan BB awal di lihat dari KMS yaitu BB 1 bulan terakhir dan BB saat penelitian diperoleh dengan menimbang BB anak secara langsung menggunakan timbangan injak digital. Data dianalisis secara deskriptif dan inferensia menggunakan uji Chi-Square.

\section{HASIL}

\section{Analisis Univariat}

\section{Kenaikan Berat Badan Setelah Diberikan Biskuit PMT-P}

Kenaikan berat badan diukur satu bulan setelah diberikan biskuit PMT-P dari Puskesmas. Distribusi frekuensi responden berdasarkan kenaikan berat badan menurut usia dapat dilihat pada Tabel 1:

Tabel 1 Distribusi Frekuensi Responden berdasarkan Kenaikan Berat Badan

\begin{tabular}{lcc}
\hline $\begin{array}{c}\text { Kenaikan Berat } \\
\text { Badan }\end{array}$ & $\begin{array}{c}\text { Frekuensi } \\
(\mathbf{n})\end{array}$ & Persentase (\%) \\
\hline $\begin{array}{l}\text { Tidak Naik }(< \\
\text { 200 gram ) }\end{array}$ & 23 & 44.2 \\
$\begin{array}{l}\text { Naik ( } \geq 200 \\
\text { gram ) }\end{array}$ & 29 & 55.8 \\
\hline \multicolumn{1}{c}{ Total } & 52 & 100 \\
\hline
\end{tabular}

Berdasarkan Tabel 1 dapat dilihat bahwa distribusi frekuensi responden berdasarkan kenaikan berat bdan setelah diberikan biskuit PMT-P dari 52 responden sebanyak

$29(55.8 \%)$ responden mengalami kenaikan berat badan setelah diberikan biscuit PMT-P.

\section{Jumlah Pemberian Biskuit PMT-P}

Jumlah pemberian biskuit PMT-P adalah banyaknya biskuit PMT-P yang dikonsumsi per hari yang sesuai dengan dalam juknis pemberian biskuit PMT-P. Distribusi frekuensi responden berdasarkan jumlah pemberian biskuit PMT-P dapat dilihat pada Tabel 2 :

Tabel 2. Distribusi Frekuensi Responden berdasarkan Jumlah Pemberian Biskuit PMT-P Per Hari

\begin{tabular}{lcc}
\hline $\begin{array}{l}\text { Jumlah } \\
\text { Pemberian PMT- } \\
\text { P }\end{array}$ & $\begin{array}{c}\text { Frekuensi } \\
\text { (n) }\end{array}$ & Persentase (\%) \\
\hline $\begin{array}{l}\text { Tidak Sesuai (< } \\
\text { 12 keping/hari) }\end{array}$ & 23 & 44.2 \\
$\begin{array}{l}\text { Sesuai ( } \geq 12 \\
\text { keping/hari) }\end{array}$ & 29 & 55.8 \\
\hline Total & 52 & 100 \\
\hline
\end{tabular}

Berdasarkan Tabel 2 dapat dilihat bahwa distribusi frekuensi responden berdasarkan jumlah pemberian biskuit 
PMT-P per hari dari 52 responden sebagian besar yaitu $29(55.8 \%)$ responden memiliki jumlah konsumsi pemberian biskuit PMT-P per hari sesuai dengan ketentuan juknis pemberian biskuit PMT-P.

\section{Analisis Bivariat}

Hubungan Jumlah Pemberian Biskuit PMT-P dengan Kenaikan Berat Badan Balita Gizi Kurang Usia 12-24 Bulan

Hasil analisis korelasi jumlah pemberian biskuit PMT-P dengan kenaikan berat badan balita gizi kurang usia 12-24 bulan dapat dilihat pada Tabel 3

Berdasarkan Tabel 3 dapat dilihat bahwa dari 23 responden yang jumlah pemberian biskuit PMT-P nya tidak sesuai terdapat $2(8.7 \%)$ responden yang naik berat badannya. Sedangkan dari 29 responden yang jumlah pemberian biskuit PMT-P nya sesuai terdapat 2 (6.9\%) responden yang tidak naik berat badannya. Hasil uji analisa statistik Chi-Square menunjukkan tingkat signifikan $\mathrm{P}$ value $=$ 0.00 dengan $\mathrm{P}$ value $<0.05$ sehingga $\mathrm{Ho}$ ditolak. Hal ini membuktikan bahwa terdapat hubungan yang signifikan antara jumlah pemberian biskuit PMT-P dengan kenaikan berat badan. Nilai POR $=13.239$ dengan POR > 1 menunjukkan jumlah pemberian biskuit PMT-P akan menaikkan berat badan sebesar 13.239 kali.

Tabel 3 Hubungan Jumlah Pemberian Biskuit PMT-P dengan Kenaikan Berat Badan Balita Usia 12-24 Bulan

\begin{tabular}{|c|c|c|c|c|c|c|c|c|}
\hline \multirow{3}{*}{$\begin{array}{l}\text { Jumlah pemberian } \\
\text { Biskuit PMT-P }\end{array}$} & \multicolumn{4}{|c|}{ Kenaikan Berat badan } & \multirow{2}{*}{\multicolumn{2}{|c|}{ Total }} & \multirow{3}{*}{$P$ value } & \multirow{3}{*}{ POR } \\
\hline & \multicolumn{2}{|c|}{$\begin{array}{l}\text { Tidak Naik < } \\
200 \text { gram }\end{array}$} & \multicolumn{2}{|c|}{$\begin{array}{l}\text { Naik } \geq 200 \\
\text { gram }\end{array}$} & & & & \\
\hline & $\mathbf{n}$ & $\%$ & $\mathbf{n}$ & $\%$ & $\mathbf{n}$ & $\%$ & & \\
\hline $\begin{array}{l}\text { Tidak Sesuai < } 12 \\
\text { kening }\end{array}$ & 21 & 91.3 & 2 & 8.7 & 23 & 100 & 0.00 & 13.239 \\
\hline Sesuai $\geq 12$ keping & 2 & 6.9 & 27 & 93.1 & 29 & 100 & & \\
\hline Total & 23 & 44.2 & 29 & 55.8 & 52 & 100 & & \\
\hline
\end{tabular}

\section{PEMBAHASAN}

\section{Hubungan Jumlah Pemberian Biskuit PMT-P dengan Kenaikan Berat Badan Pada Balita Gizi Kurang Usia 12-24 Bulan yang Mendapatkan Program Biskuit PMT-P dari Puskesmas Rawat Inap Muara Fajar}

Makanan tambahan balita adalah suplemen gizi berupa makanan tambahana dalam bentuk biskuit dengan formulasi khusus dan difortifikasi dengan vitamin dan mineral yang diberikan kepada anak balita usia 6-59 bulan dengan kategori kurus untuk mencukupi kebutuhan gizi (Santoso, 2014). Tiap kemasan primer (4 keping/ 40 gram) Makanan Tambahan Balita mengandung minimum 160 kalori, 3,2 - 4,8 gram protein, 4-7,2 gram lemak. Makanan Tambahan Balita diperkaya dengan 10 macam vitamin (A, D, E, K, B1, B2, B3, B6, B12 dan Folat) dan 7 macam mineral (Besi, Iodium, Seng, Kalsium, Natrium, Selenium, Fosfor) (Kemenkes,2018).

Hasil penelitian menunjukkan bahwa dari 23 responden yang termasuk kategori jumlah pemberian biskuit PMT-P tidak sesuai terdapat $2(8.7 \%)$ responden yang naik berat badannya dan dari 29 responden yang termasuk kategori jumlah pemberian biskuit PMT-P sesuai terdapat 2 (6.9\%) responden yang tidak naik berat badannya.

Berdasarkan hasil wawancara mendalam oleh peneliti dengan responden yang jumlah pemberian biskuit PMT-P tidak sesuai tetapi mengalami kenaikan berat badan disebabkan karena responden lebih banyak mengkonsumsi makanan tambahan lainnya seperti roti manis dengan berbagai isian didalamnya yang biasa diberikan ibu responden. Dan ada juga responden yang masih diberikan susu formula. Responden lebih sering mengkonsumsi susu formula dibandingkan 
biskuit PMT-P yang diberikan dari puskesmas. Walaupun responden tidak mengkonsumsi jumlah yang dianjurkan tetapi berat badan responden tetap naik. Perilaku responden ini muncul karena orang tua/ Ibu responden masih bisa untuk membelikannya susu formula atau makanan pendamping lainnya sebagai makanan tambahan pada balita gizi kurang.

Sedangkan responden yang jumlah pemberian biskuit PMT-P sesuai tetapi tidak mengalami kenaikan berat badan disebabkan karena adanya faktor penyerta seperti kondisi responden tidak sehat. Dalam satu bulan belakangan responden mengalami kenaikan suhu tubuh serta diare yang mengakibatkan sulitnya untuk mencapai kenaikan berat badan minimum pada responden. Kenaikan berat badan minimum pada usia 12-24 yaitu sebanyak 200 gram sementara pada responden hanya mengalami kenaikan sekitar 50-100 gram (Irianto 2014), ini dikategorikan bahwa responden tidak mengalami kenaikan berat badan dikarenakan tidak mencapai kenaikan berat badan minimum pada usia responden.

Berdasarkan analisis uji statistik menunjukan hasil $\mathrm{P}$ value $=0.00$ dengan $\mathrm{P}$ value $<0.05$ sehingga Ho ditolak. Hal ini membuktikan bahwa terdapat hubungan yang signifikan antara jumlah pemberian biskuit PMT-P dengan kenaikan berat badan. Hal ini menunjukkan bahwa jumlah pemberian biskuit PMT-P yang tidak sesuai memiliki resiko tidak naik berat badan sebesar 13.239 kali dibandingkan dengan responden yang memiliki jumlah pemberian biskuit PMT-P yang sesuai.

Hasil penelitian ini sejalan dengan penelitian yang dilakukan oleh Hoddinot $\mathbf{J}$ (2013) yang menyatakan bahwa PMT-P memberikan pengaruh signifikan terhadap perubahan status gizi $\mathrm{BB} / \mathrm{TB}$ dan $\mathrm{BB} / \mathrm{U}$ balita gizi buruk dengan memberikan rerata konstribusi energi sebanyak 54.60 \pm $15.42 \%$ dan protein $79.17 \pm 37.75 \%$ dari kebutuhan seharusnya dalam sehari. Selanjutnya penelitian T Heronimus, dkk. (2017) menunjukkan bahwa terdapat hubungan signifikan antara pemberian makanan tambahan dengan peningkatan berat badan pada bayi di Poskesdes Landungsari dengan nilai korelasi 0,620. Begitu juga dengan penelitian yang dilakukan oleh Hosang (2017) yaitu terdapat hubungan atara frekuensi dan jumlah pemberian biskuit PMT-P dengan kenaikan berat badan balita gizi kurang pada balita.

Jumlah atau porsi merupakan suatu ukuran maupun takaran makanan yang dikonsumsi pada tiap kali makan (Priantika,2013). Pemberian Makanan Tambahan pada periode usia 6-24 bulan sering tidak tepat dan tidak cukup baik kualitas maupun kuantitasnya (Aritonang, I, 2011). Makanan Tambahan Balita dalam bentuk biskuit oleh pemerintah diberikan pada balita 6-59 bulan dengan kategori kurus yang memiliki status gizi berdasarkan indeks $\mathrm{BB} / \mathrm{PB}$ atau $\mathrm{BB} / \mathrm{TB}$ dibawah -2SD. Pada balita yang diberikan makanan tambahan diperlukan pemantauan berat badan dan panjang badan/ tingi badan setiap bulannya. Untuk usia 12-59 bulan PMT balita diberikan sebanyak 12 keping (3 bungkus) setiap harinya (Wenda, dkk,2018).

\section{KESIMPULAN}

Berdasarkan uji Chi Square di dapat $\mathrm{p}$ value $<0,05$ untuk variabel jumlah yang artinya terdapat hubungan antara jumlah pemberian biskuit PMT-P dengan kenaikan berat badan balita gizi kurang usia 12-24 bulan yang mendapatkan program PMT-P dari Puskesmas Rawat Inap Muara Fajar.

\section{UCAPAN TERIMAKASIH}

Ucapan terima kasih peneliti
ucapkan kepada
Pahlawan Tuanku Tambusai

DAFTAR PUSTAKA 
Adriani M, Bambang W, (2014). Gizi dan Kesehatan Balita (Peranan Mikro Zinc pada pertumbuhan balita).Jakarta : Kencana

Aritonang I, (2013). Model Multilevel Pertumbuhan Anak Usia 0-24 Bulan dengan Variabel yang Mempengaruhinya. Jurnal Penelitian dan Evaluasi Pendidikan. Hal: 130142. Politeknik Kesehatan Kemenkes Yogyakarta.

Aritonang, (2011). Model multilevel pertumbuhan anak usia 0-24 bulan dan variabel yang mempengaruhinya. Jurnal penelitian dan evaluasi pendidikan. Yogyakarta : politeknik kesehatan kemenkes Yogyakarta hal. 130-142.

Heronimus T S, et al, (2017). Hubungan Anatara pemberian MT dengan peningkatana Berat Badan Pada Bayi 6-12 Bulan di Posyandu Wilayah Kerja Pos Kesehatan Desa (Poskesdes) Landungan Sari Kec. Dau Kab. Malang.

Hardinsyah (2019). Teori Prinsip Ilmu Gizi. Jakarta: EGC

Hoddinott J, Alderman H, Behrman JR, Haddad L, Horton S, (2013). The economic rationale for investing in stunting reduction. university of pennsylvania scholarly commons. Grand Challenges Canada Economic Returns to Mitigating Early Life Risks Project.

Hosang, Kevin, dkk, (2017). "Hubungan Pemberian Makanan Tambahan terhadap Perubahan Status Gizi Anak Balita Gizi Kurang di Kota Manado"

Irianto, Koes, (2014). Gizi Seimbang dalam Kesehatan Reproduksi (Balanced Nutrition in Reproductive Health).Bandung:ALFABETA

Kemenkes RI, (2018). Petunjuk teknis pemberian makanan tambahan (Balita-Ibu hamil- Anak sekolah). Jakarta.
Kemenkes RI, (2010). Keputusan Menteri Kesehatan Republik Indonesia N0. 1995/Menkes/SK/XII/2010 tentang Standar Antropometri Penilaian Status Gizi Anak.

Maisarah, Fatmala Umi and , dr.Burhannudin Ichsan, M.Med.Ed., M.Kes, (2018). Hubungan Status Pekerjaan Ibu, Tingkat Pendapatan Keluarga, Tingkat Pengetahuan Ibu tentang Gizi dan Pemberian ASI Eksklusif terhadap Status Gizi Balita. Skripsi thesis, Universitas Muhammadiyah Surakarta.

Priantika S, (2013). Hubungan Kebiasaan Makan dengan Dispepsia Fungsional,Jurnal Fakultas Kedokterandan Ilmu Kesehatan Universitas Jambi, Vol. 1No. 1.

Uripi.V,(2014). Menu Sehat Untuk Balita. Jakarta:Puspa Swara

Verawati B, Yanto N. 2021. Hubungan Asupan Protein dan Kerawanan Pangan dengan Kejadian Stunting padda Balita di Masa Pandemi Covid 2019. Prepotif Jurnal Kesehatan Masyarakat. Vol 5, No 1 (2021): April 2021

Wenda Merry, dkk. (2018). Pengaruh Pemberian Makanan Tambahan Pemulihan (Pmt-P) Terhadap Perubahan Skor $\mathrm{Z}$ Berat Badan Menurut Umur Balita Gizi Kurang (Studi Di Wilayah Kerja Puskesmas Makki Distrik Makki Kabupaten Lanny Jaya - Papua. Jurnal 